\title{
Emerging role of the brain in the homeostatic regulation of energy and glucose metabolism
}

\author{
Eun $\operatorname{Roh}^{1,2,4}$, Do Kyeong Song ${ }^{1,3,4}$ and Min-Seon Kim ${ }^{1,3}$
}

Accumulated evidence from genetic animal models suggests that the brain, particularly the hypothalamus, has a key role in the homeostatic regulation of energy and glucose metabolism. The brain integrates multiple metabolic inputs from the periphery through nutrients, gut-derived satiety signals and adiposity-related hormones. The brain modulates various aspects of metabolism, such as food intake, energy expenditure, insulin secretion, hepatic glucose production and glucose/fatty acid metabolism in adipose tissue and skeletal muscle. Highly coordinated interactions between the brain and peripheral metabolic organs are critical for the maintenance of energy and glucose homeostasis. Defective crosstalk between the brain and peripheral organs contributes to the development of obesity and type 2 diabetes. Here we comprehensively review the above topics, discussing the main findings related to the role of the brain in the homeostatic regulation of energy and glucose metabolism. Experimental \& Molecular Medicine (2016) 48, e216; doi:10.1038/emm.2016.4; published online 11 March 2016

\section{CENTRAL REGULATION OF ENERGY METABOLISM}

In normal individuals, food intake and energy expenditure are tightly regulated by homeostatic mechanisms to maintain energy balance. Substantial evidence indicates that the brain, particularly the hypothalamus, is primarily responsible for the regulation of energy homeostasis. ${ }^{1}$ The brain monitors changes in the body energy state by sensing alterations in the plasma levels of key metabolic hormones and nutrients. Specialized neuronal networks in the brain coordinate adaptive changes in food intake and energy expenditure in response to altered metabolic conditions (Figure 1). ${ }^{2,3}$

\section{Brain regulation of food intake}

The hypothalamus is considered a key organ in the regulation of food intake. The hypothalamic arcuate nucleus (ARC) is adjacent to the median eminence, one of the circumventricular organs, and surrounds the third cerebroventricle. Thus, hormones and nutrients in the systemic circulation and the cerebrospinal fluid can easily access the ARC. Anatomically, the ARC is considered a hypothalamic area that primarily senses metabolic signals from the periphery via the systemic circulation. ${ }^{4}$ In the ARC, there are two distinct neuronal populations: one group of neurons produces the orexigenic neuropeptides neuropeptide Y (NPY) and agouti-related peptide (AgRP), whereas the other subset of neurons expresses the anorexigenic neuropeptides proopiomelanocortin (POMC), and cocaine- and amphetamine-regulated transcript. These neurons are the first-order neurons on which peripheral metabolic hormones, including leptin, insulin, ghrelin and nutrients, primarily act. ${ }^{5}$ The anorexigenic effect of monoamine serotonin is also mediated by the $5 \mathrm{HT}-2 \mathrm{C}$ receptor in POMC neurons. ${ }^{6}$ POMC neurons project axonal processes to second-order neurons in hypothalamic areas such as the paraventricular nucleus (PVN), ventromedial hypothalamus (VMH) and lateral hypothalamus (LH), and to autonomic preganglionic neurons in the brain stem and spinal cord. ${ }^{7}$

The anorexigenic neuropeptide $\alpha$-melanocyte-stimulating hormone $(\alpha-\mathrm{MSH})$ is produced by posttranscriptional processing of POMC and is released from the presynaptic terminals of POMC neurons. Upon binding to the melanocortin- 3 and -4 receptors (MC3R and MC4R) on second-order neurons, $\alpha$-MSH activates catabolic pathways, leading to reduced food intake and increased energy expenditure. Targeted deletion of the MC4R in mice induces hyperphagia, reduces energy expenditure and leads to obesity. ${ }^{8}$ In humans, MC4R mutations account for $\sim 6 \%$ of severe early-onset obesity cases, ${ }^{9}$ suggesting an important role for the central melanocortin system in the maintenance of normal body weight.

\footnotetext{
${ }^{1}$ Appeptite Regulation Laboratory, Asan Institute for Life Sciences, University of Ulsan College of Medicine, Seoul, Korea; ${ }^{2}$ Department of Medicine, University of Ulsan College of Medicine, Seoul, Korea and ${ }^{3}$ Division of Endocrinology and Metabolism, Asan Medical Center, Seoul, Korea

${ }^{4}$ These authors contributed equally to this work.

Correspondence: Professor M-S Kim, Division of Endocrinology and Metabolism, Appetite Regulation Laboratory, Asan Institute for Life Sciences, Asan Medical Center, University of Ulsan College of Medicine, 88 Olympic-ro 43-gil, Songpa-gu, Seoul 138-736, Korea.

E-mail: mskim@amc.seoul.kr

Received 20 November 2015; revised 7 December 2015; accepted 9 December 2015
} 


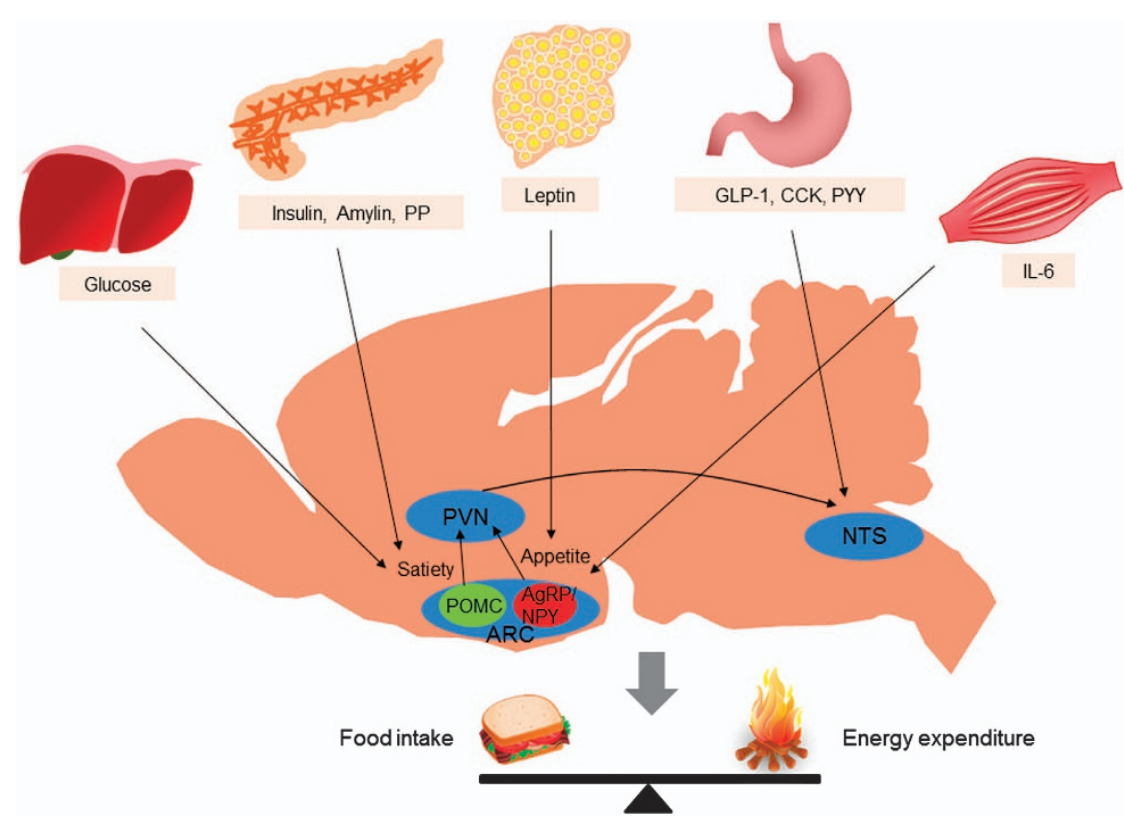

Figure 1 Integration of peripheral metabolic signals andthe central nervous system maintains energy homeostasis. The brain integrates metabolic signals from peripheral tissues such as the liver, pancreas, adipose tissue, gut and muscle. Specialized neuronal networks in the brain coordinate adaptive changes in food intake and energy expenditure in response to altered metabolic conditions. Neuropeptide Y/agouti-related protein- and proopiomelanocortin-producing neurons in the hypothalamic arcuate nucleus primarily sense the body energy state. These neurons project to other hypothalamic nuclei and to the nucleus of the solitary tract in the brain stem to control multiple aspects of the homeostatic regulation of energy balance. ARC, arcuate nucleus; CCK, cholecystokinin; GLP-1, glucagon-like peptide-1; IL-6, interleukin-6; PP, pancreatic polypeptide; PVN, paraventricular nucleus; PYY, peptide YY.

The endogenous MC-3/4R antagonist AgRP is released from the terminals of NPY/AgRP-producing neurons to the synaptic space of second-order neurons where it competes with $\alpha$-MSH for MC3Rs and MC4Rs and antagonizes its effects. ${ }^{10}$ Selective ablation of NPY/AgRP neurons in young mice results in a significant decrease in food intake and body weight, ${ }^{11}$ suggesting that these neurons are critical for promoting food intake and preventing weight loss. Administration of NPY stimulates food intake via Y1 or Y5 receptors. ${ }^{12}$ NPY is required for the rapid stimulation of feeding, whereas AgRP stimulates feeding over a prolonged period. ${ }^{13}$

PVN neurons synthesize and secrete neuropeptides that have a net catabolic action, including corticotrophin-releasing hormone, thyrotropin-releasing hormone, somatostatin, vasopressin and oxytocin. On the other hand, PVN neurons control sympathetic outflow to peripheral metabolic organs, resulting in increased fatty acid oxidation and lipolysis. ${ }^{14}$ Destruction of PVN and haploinsufficiency of Sim1, a critical transcriptional factor in the development of PVN, cause hyperphagia and obesity, ${ }^{15}$ implying a inhibitory role of the PVN in food intake and weight gain.

The VMH mainly receives neuronal projections from the $\mathrm{ARC}$ and projects their axons to the ARC, dorsomedial nucleus $(\mathrm{DMN}), \mathrm{LH}$ and brain stem regions. The VMH contains neurons that sense glucose and leptin. ${ }^{16,17}$ Moreover, the anorexigenic neuropeptide brain-derived neurotrophic factor is produced in the VMH. ${ }^{18}$ Destruction of the VMH causes hyperphagia, obesity and hyperglycemia. ${ }^{19}$ Thus, the VMH is regarded a pivotal area in generating satiety and maintaining glucose homeostasis. The DMN contains a high level of NPY terminals and $\alpha-\mathrm{MSH}$ terminals originating from the ARC. ${ }^{20}$ Destruction of the DMN also results in hyperphagia and obesity. $^{21}$

In contrast to the PVN, VMH and DMN, destruction of the LH leads to hypophagia and weight loss. Therefore, LH is considered a feeding center. LH contains two neuronal populations producing the orexigenic neuropeptides melanin-concentrating hormone $(\mathrm{MCH})$ and orexin, also called hypocretin. NPY/AgRP- and $\alpha$-MSH-immunoreactive terminals from ARC neurons are in contact with $\mathrm{MCH}-$ and orexin-expressing neurons. ${ }^{22}$ Orexin-producing neurons are also involved in glucose sensing and the regulation of sleep-awake cycles. ${ }^{23}$ Alterations in the orexin receptor- 2 and orexin genes produce narcolepsy in animal models and humans. ${ }^{24}$ On the other hand, depletion of $\mathrm{MCH}$ or the $\mathrm{MCH}-1$ receptor in mice attenuates weight gain, suggesting that $\mathrm{MCH}$ is an endogenous orexigenic molecule. ${ }^{25}$

The brain stem is another key brain area involved in the regulation of food intake. Satiety signals from the gastrointestinal tract are relayed to the nucleus tractus solitaries (NTS) through the sensory vagus nerve, a major neuronal connection between the gut and brain. Transection of sensory vagal fibers decreases meal size and meal duration, confirming that vagal afferents transfer meal-related signals to the brain. ${ }^{26}$ Like the ARC, the NTS is anatomically close to the area postrema, another circumventricular organ. ${ }^{27}$ Therefore, the NTS is perfectly located for receiving both humoral and neural signals. Meanwhile, the NTS receives extensive neuronal 
projections from the PVN and vice versa, ${ }^{28}$ indicating that there are intimate communications between the hypothalamus and the brain stem. Like hypothalamic neurons, NTS neurons produce appetite-regulating glucagon-like peptide-1 (GLP-1), NPY and POMC, and sense peripheral metabolic signals. ${ }^{29}$ For instance, NTS POMC neurons show the signal transducer and activator of transcription 3 (STAT3) activation in response to exogenous leptin. ${ }^{30}$ Thus, circulating hormones and nutrients may relay metabolic signals to the brain by acting on both the hypothalamus and brain stem.

On the other hand, the brain reward system is involved in the control of hedonic feeding, that is, intake of palatable foods. Like other addiction behaviors, the mesolimbic and mesocortical dopaminergic pathways are involved in hedonic feeding. Intake of palatable foods elicits dopamine release in the ventral tegmental area (VTA), which in turn activates the neural pathways from the VTA to the nucleus accumbens via the medial forebrain bundles. Interestingly, hedonic feeding is modulated by metabolic signals. Leptin acts on the dopaminergic neurons in the VTA to suppress feeding. ${ }^{31}$ Conversely, hedonic feeding can override satiety signals. Mice lacking the $\mathrm{D}_{2}$ receptor are more sensitive to leptin. ${ }^{32}$

\section{Brain regulation of energy expenditure}

The brain modulates various processes that consume energy, such as locomotor activity, fatty acid oxidation in the skeletal muscle and thermogenesis. ${ }^{33}$ Tumor growth factor- $\alpha$, produced in the suprachiasmatic nucleus in a circadian manner, strongly inhibits locomotor activity by acting on the epidermal growth factor receptors expressed in the hypothalamic subparaventricular zone. ${ }^{34}$ Orexin-A produced by LH neurons promotes locomotor activity and wakefulness through orexin-1 and orexin-2 receptors. ${ }^{35} \mathrm{~A}$ role for orexin in food-seeking behavior in food-deprived conditions has been suggested. ${ }^{36}$ Leptin stimulates locomotor activity via a mechanism that depends on hypothalamic POMC neurons ${ }^{37}$. Leptin also enhances fatty acid oxidation in skeletal muscle via both central and peripheral mechanisms. ${ }^{38}$

Thermogenesis is theprocess that dissipates energy as heat to maintain body temperature. Thermogenesis mainly occurs in brown adipose tissue (BAT). ${ }^{39}$ Brown fat-like adipocytes, so-called browning of white adipose tissue (WAT), are found in the subcutaneous inguinal WAT under certain circumstances. Cold exposure or intracerebroventricular (ICV) coinjection of insulin and leptin induces WAT browning. ${ }^{40}$ Induction of WAT browning results in increased energy expenditure and attenuation of diet-induced obesity in mice. Conversely, inhibition of WAT browning by depletion of Prdm16 leads to obesity. ${ }^{39}$

The brain regulates BAT thermogenesis through modulation of the sympathetic nervous system. Norepinephrine released from sympathetic nervous terminals acts on the $\beta 3$-adrenergic receptors in adipocytes in the BAT and inguinal fat pads. Activation of adrenergic receptors triggers cyclic-adenosine monophosphate signaling, which in turn increases the expression of uncoupling protein- 1 in the mitochondria. BAT thermogenesis is important for maintaining body temperature in response to cold exposure and dissipating excess energy after high-calorie intake. Because metabolic fuel substrates such as glucose and fatty acid are consumed during BAT thermogenesis, BAT thermogenesis can affect body weight and body fat mass. ${ }^{41}$ In the past, BAT was thought to be present only in human infants. However, ${ }^{18} \mathrm{~F}$-fluorodeoxyglucose positron emission tomography revealed the presence of BAT in the adult humans. Human BAT depots are distributed in the supraclavicular area and in perivascular and periviscus areas (for example, around the heart, airway, gut, liver and adrenal gland) of the chest and abdomen. ${ }^{42}$ BAT activity, determined by ${ }^{18} \mathrm{~F}$-fluorodeoxyglucose positron emission tomography, is affected by outdoor temperature, age, sex, body mass index and the coexistence of diabetes. Because the amount of BAT is inversely correlated with body mass index, especially in older subjects, a potential role of BAT in adult human metabolism has been suggested. ${ }^{43}$

In thermogenic regulation, the hypothalamus integrates the sensation of body temperature with efferent sympathetic outflow. Hypothalamic areas such as the prooptic area, VMH, DMN and ARC modulate thermogenic activity by influencing the sympathetic nervous system. ${ }^{44}$ The prooptic area is an important area in the control of body temperature. ${ }^{45}$ VMH was the first hypothalamic nucleus to be studied regarding the regulation of BAT activity. The DMN also contains sympathoexcitatory neurons, ${ }^{46}$ which regulate thermogenic activity. ${ }^{47,48}$ BAT thermogenesis is also related to the ARC melanocortin system because $\alpha$-MSH stimulates BAT activity. ${ }^{49}$

Hormonal- and nutrient-mediated metabolic signals can influence sympathetic outflow to the BAT. Central administration of leptin, MC3/4R agonist, glucagon and GLP-1 stimulates BAT activity. ${ }^{50,51}$ Central administration of insulin either stimulates or inhibits BAT thermogenesis, depending on the insulin dose. Central administration of high doses of insulin increases sympathetic nerve activity in the BAT, whereas low doses of insulin decrease it. ${ }^{52,53}$ Food consumption or dietary composition also affects BAT thermogenesis. Although the mechanism of postprandial thermogenesis is unclear, norepinephrine turnover in the BAT is increased after a meal. ${ }^{54}$ Glucose administration increases thermogenesis, whereas fasting or food restriction inhibits thermogenesis. Low-protein diet and high-fat diet increase BAT activity. ${ }^{55}$

\section{Peripheral signals modulating energy metabolism}

Adiposity signals. Adiposity signals refer to the peripheral signals that circulate in proportion to the total amount of stored fat and inform the brain about the stored energy state. They modulate energy balance through the regulation of food intake and energy expenditure. ${ }^{2,56}$ Insulin is a hormone that was first identified as an adiposity signal. ${ }^{5,57}$ Insulin is secreted by $\beta$-cells in response to energy flux. Plasma insulin concentrations increase in proportion to the amount of stored fat. ${ }^{58}$ When insulin is administered directly into the central nervous system, it induces a dose-dependent reduction in food intake 
and body weight. ${ }^{59,60}$ Thus, insulin is thought to signal adiposity to the brain. In hypothalamic neurons, insulin activates the insulin receptor substrate-2 (IRS2)-phosphatidylinositol 3-kinase (PI3K) signaling pathway. Neuronal deletion of insulin receptor and IRS2 results in increased food intake and susceptibility to diet-induced obesity. ${ }^{61,62}$

The adipose tissue-derived hormone leptin was discovered by positional cloning of the obesity locus $(o b)$ in $1994 .{ }^{63}$ Leptin is now considered a representative adiposity signal. ${ }^{64}$ The receptors activated by leptin are highly expressed in several regions of brain, including the hypothalamus. ${ }^{65}$ Genetic deficiency in leptin or the long-form leptin receptor (LepRb) is associated with hyperphagia, hypoactivity and obesity. ${ }^{66}$ Of several brain regions, the ARC is an important area that mediates leptin actions. Injection of leptin directly into the ARC reduces food intake and body weight. ${ }^{67}$ Leptin also stimulates locomotion through signaling in POMC neurons. ${ }^{37}$ Consistently, ICV administration of leptin in leptin-deficient $(o b / o b)$ mice attenuates obesity. ${ }^{66}$ In hypothalamic neurons, leptin provokes several signaling cascades such as the Janus kinase-STAT pathway, IRS-PI3K signaling, the mammalian target of rapamycin-S6 kinase signaling, AMP-activated protein kinase (AMPK) signaling and ERK signaling. ${ }^{68}$ Of those, STAT3 signaling represents hypothalamic leptin signaling and is frequently used as a marker of leptin signaling activity.

Nutrient signals. Nutrients such as glucose, fatty acids and amino acids provide information on nutrient availability to the brain. Glucose signals the presence of anenergy supply to the brain, whereas hypoglycemia signals an energy deficit. ${ }^{69}$ Thus, central administration of glucose and long-chain fatty acids decreases food intake. ${ }^{70}$ In contrast, ICV administration of the glucose anti-metabolite 2-deoxy-D-glucose increases food intake. ${ }^{71}$ The malonyl-CoA content in hypothalamic neurons has been suggested to be a fuel gauge. ${ }^{56,72}$ Administration of the fatty acid synthase inhibitor C75 induces accumulation of malonyl-CoA in hypothalamic neurons, leading to decreased food intake and body weight. ${ }^{73}$ Long-chain fatty acyl-CoA (LCFA-CoA) content in hypothalamic neurons also acts as a cellular nutrient sensor. An increased hypothalamic LCFA-CoA level due to ICV long-chain fatty acid (LCFA) administration leads to decreased food intake. ${ }^{70}$ Hypothalamic inhibition of carnitine palmitoyltransferase- 1 inhibits food intake by elevating LCFA-CoA content in hypothalamic neurons. ${ }^{74}$

Gastrointestinal signals. Hormones secreted by the gut in response to a meal provide information on energy intake. Cholecystokinin, peptide YY and GLP-1 released from the gut induce satiety by acting on the vagus nerve or in the brain. ${ }^{75}$ For example, GLP-1 is secreted from intestinal L-cells after a meal. GLP-1 receptors are prevalent in vagus nerve terminals, ${ }^{76}$ as well as in the central nucleus of the amygdala, the PVN and ARC of the hypothalamus, and the caudal brain stem. ${ }^{77}$ Both central and peripheral administration of GLP-1 promotes satiety. ${ }^{78,79}$ In contrast, ghrelin is secreted by the stomach during a fast and promotes food intake. ${ }^{80}$
Signals from other organs. Interleukin-6 (IL-6) is synthesized and released from contracting skeletal muscle during exercise. The elevation in the plasma IL-6 concentration during exercise correlates with exercise intensity and duration and the muscle mass recruited. ${ }^{81}$ IL- 6 enters the brain across the blood-brain barrier. IL-6 may mobilize fat from storage sites to provide energy to the muscle. ICV administration of IL-6 stimulates energy expenditure, and mice lacking IL-6 develop matureonset obesity. ${ }^{82}$

Hormones secreted from the endocrine pancreas are also involved in energy homeostasis. Insulin and amylin are co-secreted by $\beta$-cells. Like insulin, amylin acts as a satiety signal and reduces food intake via amylin receptors in the area postrema. Other brain sites mediating amylin action include the NTS and the lateral parabrachial nucleus. ${ }^{83}$ Amylin also acts as an adiposity signal because amylin levels are well correlated with body fat content. Glucagon, a counterregulatory hormone to insulin, is secreted from $\alpha$-cells. Glucagon reduces meal size by acting on the vagus nerves and stimulates energy expenditure through central and peripheral mechanisms. ${ }^{84}$ Pancreatic polypeptide is also secreted from the endocrine pancreas. Pancreatic polypeptide regulates gastric motility, pancreatic exocrine secretion and food intake. Systemic administration of pancreatic polypeptide reduces food intake and weight gain. ${ }^{85}$ The anorectic effect of pancreatic polypeptide is mediated by $\mathrm{Y} 4$ receptors in the dorsal vagal complex. ${ }^{86}$

\section{BRAIN REGULATION OF GLUCOSE METABOLISM}

The earliest demonstration of the role of the brain in glucose homeostasis was provided by the physiologist Claude Bernard in 1854. Dr Bernard demonstrated that a puncture in the floor of the fourth ventricle of the rabbit brain resulted in glycosuria. ${ }^{87}$ In the past few decades, the concept of central regulation of glucose metabolism has been further established by the subsequent discovery of glucose-sensing neurons in the hypothalamus ${ }^{88,89}$ and the demonstration of their roles in maintaining normal glucose levels. ${ }^{90}$ A specialized neuronal population in the brain senses hormones (insulin and leptin) and nutrients (glucose and fatty acids) to regulate glucose homeostasis. The major sites of convergence of these metabolic signals are the hypothalamus and brain stem (Figure 2).

\section{Neuronal populations controlling glucose metabolism}

Brain regions related to the control of glucose metabolism contain neurons whose excitability changes with alterations in glucose concentrations in the extracellular fluid. These glucosesensing neurons are found in the hypothalamic nuclei and brain stem, which are also important areas in the control of energy balance. Glucose-sensing neurons are subgrouped into two types. Glucose-excited neurons are excited when extracellular glucose levels increase. In contrast, glucose-inhibited neurons are activated by a fall in extracellular glucose concentrations. ${ }^{91}$ Glucose-excited neurons are mostly located in the $\mathrm{VMH}$, the $\mathrm{ARC}$ and the $\mathrm{PVN},{ }^{92}$ whereas glucoseinhibited neurons are distributed in the LH, ARC and 


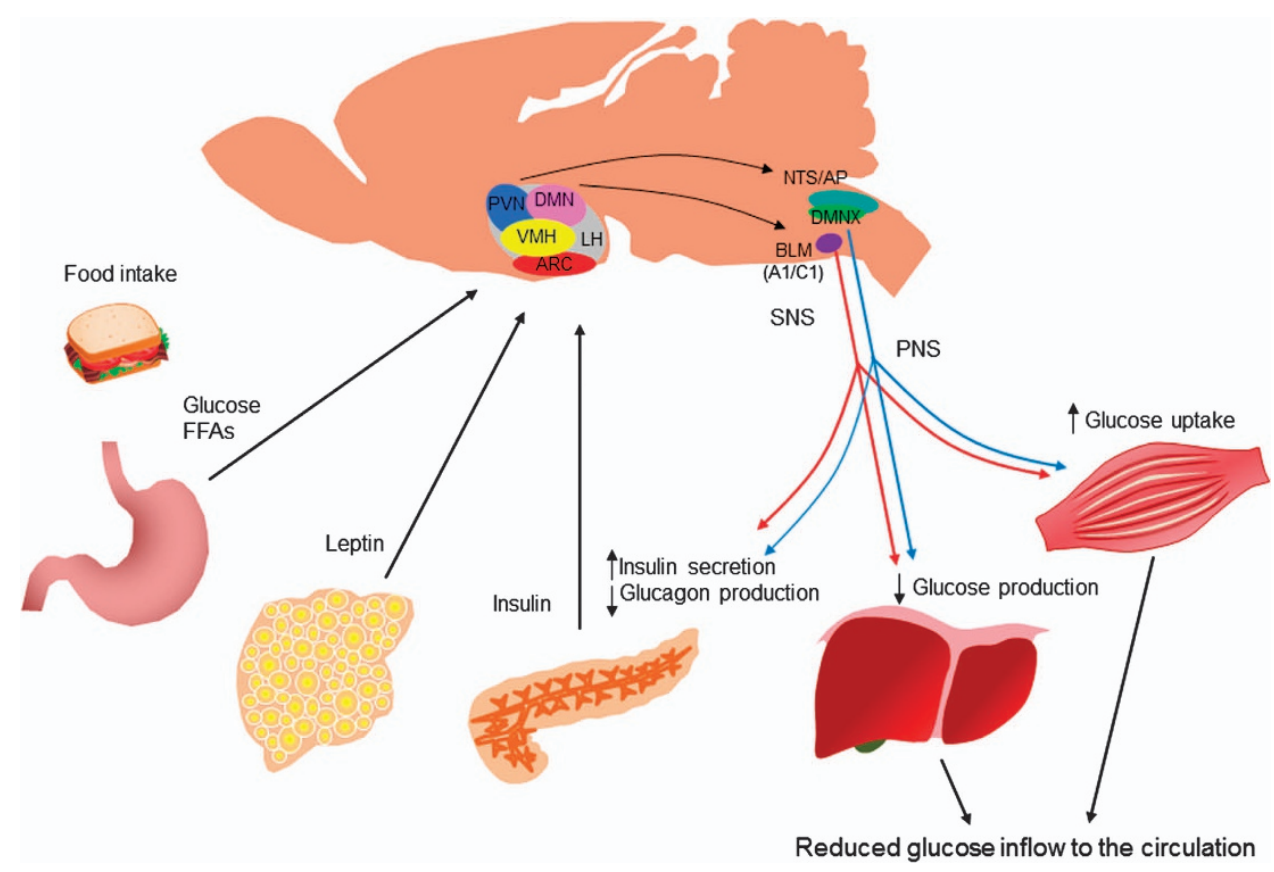

Figure 2 Brain regulation of glucose homeostasis. The brain senses peripheral metabolic signals through hormones (insulin, leptin and so on) and nutrients (glucose, free fatty acids and so on) to regulate glucose metabolism. The sites of the convergence of these metabolic signals are the hypothalamus and brain stem. The autonomic nervous system intervenes in the brain and peripheral metabolic organs to modulate pancreatic insulin/glucagon secretion, hepatic glucose production and skeletal muscle glucose uptake. AP, area postrema; ARC, arcuate nucleus; BLM, basolateral medulla; DMN, dorsomedial nucleus; DMNX, dorsal motor nucleus of the vagus; FFA, free fatty acids; LH, lateral hypothalamus; NTS, nucleus of the solitary tract; PNS, parasympathetic nervous system; PVN, paraventricular nucleus; SNS, sympathetic nervous system; VMH, ventromedial hypothalamus.

PVN. ${ }^{89,91}$ Both types of neurons are also located in the dorsal vagal complex in the brain stem, which encompasses the NTS, area postrema and the dorsal motor nucleus of the vagus. ${ }^{93-95}$

\section{Peripheral signals affecting brain regulation of glucose metabolism}

Insulin. During the past decade, the brain has been recognized to be a site of insulin action with regard to glucose homeostasis. Obici et al. ${ }^{96}$ showed that insulin acts on the brain to modulate hepatic glucose metabolism. They showed, by injecting insulin receptor antisense oligonucleotides into the cerebroventricle, that inhibition of central insulin action impaired insulin-mediated suppression of hepatic glucose production (HGP) during hyperinsulinemic clamp studies in rats. They also demonstrated that infusion of insulin into the cerebroventricle suppressed HGP, irrespective of circulating insulin levels. Moreover, central administration of insulin antibodies or inhibitors of the downstream signaling of insulin diminished the ability of insulin to inhibit glucose production. ${ }^{97}$ The hypothalamic insulin signaling pathway was investigated in subsequent studies. Overexpression of the insulin signaling molecules IRS2 and Akt in the hypothalamus enhances the glucose-lowering effect of insulin in streptozotocin-induced diabetic rats. ${ }^{98}$ These data support a role for hypothalamic insulin actions in controlling glucose metabolism in peripheral organs.

The ATP-sensitive potassium $\left(\mathrm{K}_{\mathrm{ATP}}\right)$ channel mediates insulin actions in hypothalamic neurons. ${ }^{99}$ Activation of neuronal $\mathrm{K}_{\mathrm{ATP}}$ channels by ICV injection of a $\mathrm{K}_{\mathrm{ATP}}$ channel activator (diazoxide) lowers glucose production, ${ }^{100}$ whereas infusion of a $\mathrm{K}_{\mathrm{ATP}}$ blocker (sulfonylurea) negates the glucose production-lowering effect of centrally and peripherally administered insulin..$^{96,100}$ Moreover, mice lacking the sulfonylurea receptor subunit SUR1 of the $\mathrm{K}_{\mathrm{ATP}}$ channel show a diminished response to central insulin action. ${ }^{100}$ Vagal efferent fibers constitute the brain-liver axis of insulin actions because hepatic vagotomy blocks central insulin actions. ${ }^{100}$ Interestingly, ICV infusion of insulin increases hepatic IL-6 expression, which leads to the activation of hepatic STAT3 signaling. ${ }^{101}$ Activated STAT3 inhibits FoxO1 activity and gluconeogenic gene expression in the liver. Collectively, central insulin actions are mediated via neuronal $\mathrm{K}_{\mathrm{ATP}}$ channel-vagus nerve-hepatic IL6/STAT3 signaling, although the detailed mechanisms involved remain to be determined.

Leptin. Leptin has an important role in the control of glucose metabolism. A lack of leptin (ob/ob mice) or its functional receptor ( $d b / d b$ mice) leads not only to obesity, but also metabolic derangement, including insulin resistance and diabetes. ${ }^{102}$ Leptin treatment of $o b / o b$ mice improves glucose homeostasis. ${ }^{103,104}$ Notably, acute leptin treatment via both systemic and central routes in $o b / o b$ mice restores glucose metabolism independently of changes in food intake and adiposity. ${ }^{105,106}$ Consistently, leptin-treated $o b / o b$ mice display a marked reduction in serum glucose and insulin concentrations. ${ }^{107}$ Leptin treatment in lipodystrophy mice 
improves insulin resistance and hyperglycemia independently of food intake. ${ }^{108,109}$ Thus, leptin regulates glucose homeostasis independently of its anorectic effects.

The hypothalamus is a key site of action of leptin-mediated control of glucose metabolism. ICV administration of leptin in the lipodystrophy mice model corrects insulin resistance and improves impaired insulin signaling in the liver. In contrast, peripheral injection of the same dose of leptin did not have a similar effect. ${ }^{110}$ Acute ICV injection of leptin suppresses glycogenolysis and reduces hepatic insulin resistance induced by high-fat feeding. ${ }^{111}$ Restoration of leptin signaling in the unilateral ARC by viral gene therapy in leptin receptor-null mice markedly improves hyperinsulinemia and normalizes blood glucose levels, with a mild decrease in body weight and food intake. These data demonstrate that leptin signaling in the ARC is critical for the maintenance of glucose homeostasis. ${ }^{112}$

Leptin-mediated regulation of glucose metabolism is mediated by hypothalamic STAT3 and PI3K signaling pathways. As in $d b / d b$ mice, $s / s$ mice with a mutated leptin receptor, which are unable to activate STAT3, exhibit severe hepatic insulin resistance. ${ }^{113}$ Blockade of leptin-induced STAT3 activation in the hypothalamus abolishes the suppressive effect of leptin on HGP, confirming the importance of leptin-induced STAT3 signaling. ${ }^{113}$ Conversely, hypothalamic deletion of suppressor of cytokine signaling 3 , a negative regulator of STAT3 signaling, enhances leptin sensitivity and improves glucose metabolism. ${ }^{114}$ On the other hand, reconstitution of leptin receptors in the ARC of leptin-receptor-deficient $\mathrm{fa}^{\mathrm{k}} / \mathrm{fa}^{\mathrm{k}}$ rats improves insulin sensitivity, which is attenuated by ICV infusion of PI3K inhibitor. Consistently, ARC expression of constitutively active Aktin $\mathrm{fa}^{\mathrm{k}} / \mathrm{fa}^{\mathrm{k}}$ rats mimics the effect of restored hypothalamic leptin signaling. ${ }^{115}$ These findings indicate that PI3K-Akt signaling mediates leptin actions on glucose homeostasis.

Glucose. Glucose sensing in the hypothalamus is important in glucose homeostasis. Injection of 2-deoxy-D-glucose into the VMH increases plasma glucose levels by elevating plasma glucagon and catecholamine levels. ${ }^{116}$ Conversely, intra-VMH glucose infusion suppresses counter-regulatory hormonal responses to hypoglycemia. ${ }^{90}$ The brain stem is also involved in glucoprivic feeding and counter-regulatory hormone secretion during hypoglycemia. Injection of another glucose anti-metabolite, 5-thio-D-glucose, into the NTS and the basolateral medulla, which contain $\mathrm{A} 1 / \mathrm{Cl}$ catecholaminergic neurons projecting to the hypothalamic PVN and ARC, induces feeding and glucose responses, as seen in hypoglycemia. ${ }^{117}$ Similarly, destruction of hindbrain catecholaminergic neurons by immunotoxins blocks 2-deoxyD-glucose-induced feeding and blood glucose responses. ${ }^{118}$

The glucose-sensing mechanisms in hypothalamic neurons are similar to those in pancreatic $\beta$-cells. ${ }^{119}$ Glucose signaling in glucose-excited neurons requires glucose uptake via the type 2 glucose transporter, which is followed by glucose phosphorylation by glucokinase, intramitochondrial glucose oxidation, and an increased cellular ATP/ADP ratio. This leads to the closure of ATP-sensitive $\mathrm{K}_{\mathrm{ATP}}$ channels, depolarization of the membrane potential, and influx of $\mathrm{Ca}^{2+}$ through voltagedependent calcium channels, which stimulate neuronal activity and neurotransmitter release. ${ }^{120}$ The role of hypothalamic type 2 glucose transporter, glucokinase and $\mathrm{K}_{\mathrm{ATP}}$ channels in sensing hypoglycemia and counter-regulatory hormone responses has been demonstrated. ${ }^{121-126}$ How glucose inhibits neuronal activity in glucose-inhibited neurons is unclear. One possibility is that glucose increases the ATP/ADP ratio, which stimulates the $\mathrm{Na}^{+} / \mathrm{K}^{+}$-ATPase pump and triggers hyperpolarizing currents. ${ }^{127}$ Alternatively, glucose-induced activation of ATP-dependent $\mathrm{Cl}^{-}$channels may induce hyperpolarization of the plasma membrane. ${ }^{91,128}$

AMPK functions as a 'fuel gauge' that monitors cellular energy status and provokes adaptive responses to maintain cellular energy levels ${ }^{129,130}$. ICV administration of glucose suppresses feeding via inhibition of hypothalamic AMPK activity. ${ }^{131,132}$ Hypothalamic AMPK activation is critical for feeding and counter-regulatory responses to hypoglycemia. ${ }^{131}$ Intra-VMH administration of AICAR (5-aminoimidazole-4carboxamide ribonucleotide), a chemical AMPK activator, increases HGP without changing the plasma levels of counter-regulatory hormones. ${ }^{133}$ AMPK activation in the VMH restores reduced counter-regulatory responses induced by repeated hypoglycemia. ${ }^{134}$ Consistent with these findings, inhibition of hypothalamic AMPK activity attenuates the counter-regulatory response during hypoglycemia. ${ }^{135}$

Fatty acids. LCFA signals nutrient availability to the brain and modulates peripheral glucose metabolism. ${ }^{70}$ ICV administration of oleic acid suppresses HGP during basal insulin clamping. ICV administration of $\mathrm{K}_{\mathrm{ATP}}$ channel blocker attenuates the inhibitory effect of oleic acid on glucose production, indicating an involvement of brain $\mathrm{K}_{\mathrm{ATP}}$ channels in this process. ${ }^{70}$ Increased LCFA-CoA levels in hypothalamic neurons suppresses endogenous glucose production. ${ }^{74}$ Pharmacological inhibition of hypothalamic esterification of fatty acids or surgical resection of the hepatic branch of the vagus nerve increases HGP. ${ }^{136}$ Therefore, hypothalamic lipid sensing regulates glucose homeostasis via a mechanism involving the esterification of LCFAs to LCFA-CoAs, intact $\mathrm{K}_{\mathrm{ATP}}$ channels and vagal outflow to the liver.

Effector pathways in the brain control of glucose metabolism To the liver. In rodents, direct action of insulin on the liver is necessary, but is insufficient to inhibit HGP, unless the indirect brain pathway is not fully functional. Restoration of insulin receptor expression in either the liver or brain of insulin receptor-null mice does not completely restore the ability of insulin to inhibit HGP. ${ }^{137}$ In contrast, restoration of insulin receptor expression in both the brain and liver normalizes insulin actions on HGP. ${ }^{138}$ Whether neuronal control of HGP is unique to rodents remains uncertain. ICV insulin infusion in the dog augments hepatic glucose uptake and glycogen synthesis without altering HGP, ${ }^{139}$ indicating that the 
regulation of gluconeogenesis by brain insulin signaling may differ among species. The basal HGP rate per weight is almost 5-10 times higher in rodents than in dogs and humans. ${ }^{140}$ Dogs and humans maintain hepatic glycogen storage even after a 42 -h fasting. ${ }^{141,142}$ In contrast, hepatic glycogen content is significantly depleted in rodents after a relatively short fast, which may be due to higher metabolic rates. ${ }^{143}$ Therefore, the contribution of the gluconeogenic pathway to HGP may be greater in rodents than in animals with a larger body size. ${ }^{139}$ Thus, changes in gluconeogenesis may be more easily detected in rodents.

To the skeletal muscle. Electrical stimulation of $\mathrm{VMH}$ neurons and local injection of leptin into the VMH increases glucose uptake in the skeletal muscle of rats independently of circulating insulin levels. ${ }^{144,145}$ These effects appears to be mediated by the sympathetic nervous system as they are abolished by blockade of the sympathetic nervous system. ${ }^{146,147}$ Consistently, central infusion of leptin improves glucose tolerance and enhances insulin-stimulated Akt phosphorylation in skeletal muscle. ${ }^{148,149}$ Activated Akt leads to translocation of the glucose transporter GLUT4 from its sequestered cytoplasmic location to the cell membrane, facilitating glucose uptake $^{150}$.

In the skeletal muscle, AMPK activation is induced by muscle contraction and adrenergic agonist and mediates insulin-independent glucose uptake. ${ }^{151}$ Leptin activates skeletal muscle AMPK through the hypothalamus and sympathetic nervous system. ${ }^{152}$ Therefore, leptin may promote glucose uptake to the skeletal muscle through the sympathetic nervous system-muscle AMPK signaling pathway. On the other hand, orexin-producing neurons in the LH are activated by sweet foods. Orexin regulates skeletal muscle glucose uptake through VMH neurons expressing orexin receptors and the sympathetic nervous system. ${ }^{153}$

To the pancreas. The autonomic nervous system controls the secretion of insulin and glucagon in the pancreas. Sympathetic and parasympathetic nerve endings are foundin pancreatic islets. ${ }^{154}$ Moreover, $\alpha$ - and $\beta$-cells express neurotransmitter receptors. ${ }^{155}$ Both sympathetic and parasympathetic nerve branches can stimulate glucagon secretion. In contrast, parasympathetic branches stimulate insulin secretion, whereas sympathetic branches inhibit it. ${ }^{156}$ Neurons in the dorsal motor nucleus of the vagus project nerve terminals to the pancreatic ganglions via the vagus nerve, and thus vagus nerves connect the dorsal motor nucleus of the vagus and endocrine pancreas. ${ }^{157}$

Insulin regulates whole-body glucose metabolism by acting on the brain, and modulating insulin and glucagon secretion. ICV administration of insulin increases pancreatic insulin output, demonstrating that pancreatic $\beta$-cells are influenced by insulin-sensitive cells of the brain. ${ }^{158}$ Moreover, insulin injection into the VMH inhibits glucagon secretion by pancreatic $\alpha$-cells, indicating that insulin controls glucagon secretion via brain-mediated mechanisms. ${ }^{159}$ Taken together,

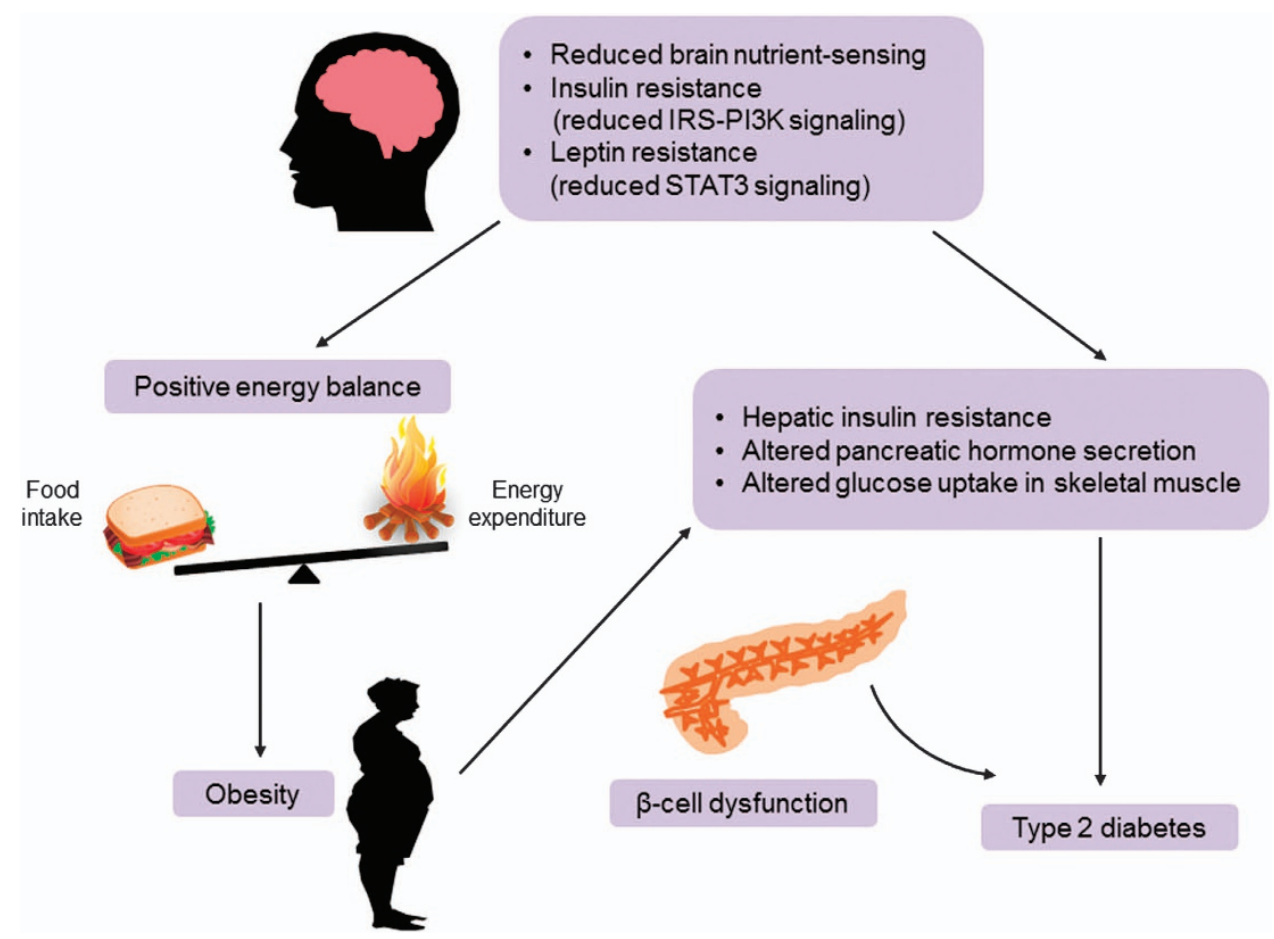

Figure 3 Pathogenesis of obesity and type 2 diabetes due to defective central regulation of energy and glucose homeostasis. Reduced nutrient sensing and impaired insulin and leptin signaling in the hypothalamus may result in a positive energy balance and predispose weight gain, causing insulin resistance in peripheral metabolic organs. Obesity-associated insulin resistance may lead to type 2 diabetes when it is combined with $\beta$-cell dysfunction. IRS, insulin receptor substrate; PI3K, phosphatidylinositol 3 kinase; STAT3, signal transducer and activator of transcription 3 . 
the brain, especially the hypothalamus and brain stem, modulates pancreatic insulin and glucagon secretion via the parasympathetic and sympathetic efferent nerves that innervate pancreatic $\alpha$ - and $\beta$-cells. ${ }^{160}$

\section{DYSREGULATION OF ENERGY/GLUCOSE METABOLISM IN OBESITY AND DIABETES}

In healthy conditions, energy intake matches energy expenditure to maintain normal body weight. Impaired ability of the brain to maintain energy homeostasis may underlie pathological weight gain and obesity (Figure 3). Several defects in the negative-feedback pathway in energy homeostatic mechanisms have been suggested. ${ }^{3}$ Defects in the secretion of key metabolic hormones such as insulin and leptin may predispose weight gain. Because leptin primarily acts on hypothalamic neurons to regulate the energy balance, leptin transfer to the brain may be critical for its action. ${ }^{5}$ Leptin concentrations in the plasma increase in proportion to body mass index, an indicator of fat mass. However, the increase in leptin concentrations in the cerebrospinal fluid of obese individuals is less than that of plasma leptin concentrations. ${ }^{161}$ Therefore, reduced leptin transport to the brain may be due to reduced action of leptin in obesity.

Defective hypothalamic sensing of these hormones favors a positive energy balance because loss of leptin receptors in the hypothalamus leads to obesity in mice. ${ }^{13}$ Rats with dietinduced obesity have reduced expressions of leptin receptors in the hypothalamus. ${ }^{162}$ Impaired postreceptor signaling in hypothalamic neurons may also result in pathological weight gain. Disruption of the hypothalamic IRS-PI3K signaling pathway causes resistance to peripheral metabolic signals and leads to obesity. ${ }^{163}$ Likewise, mice with disrupted neuronal STAT3 signaling develop hyperphagia and obesity. ${ }^{164}$

In rodents, long-term high-fat feeding reduces the anorectic response and hypothalamic STAT3 activation induced by leptin, which is called leptin resistance. ${ }^{165}$ Increased hypothalamic expression of suppressor of cytokine signaling 3 has been suggested to be a mechanism of hypothalamic leptin resistance. Ablation of suppressor of cytokine signaling 3 expression in neurons mitigates high-fat diet-induced weight gain and hyperleptinemia and improves glucose tolerance and insulin sensitivity. ${ }^{166}$ Protein-tyrosine phosphatase $1 \mathrm{~B}$, a well-known negative regulator of insulin and leptin signaling, ${ }^{167,168}$ has also been suggested to cause leptin and insulin resistance in hypothalamic neurons. Neuronal Protein-tyrosine phosphatase 1B knockout mice are hypersensitive to exogenous leptin and insulin, and display improved glucose tolerance during chronic high-fat feeding. ${ }^{169}$ Increased IKK $\beta$-NFKB and endoplasmic stress have been found in the hypothalamus of obese rodents and shown to disrupt hypothalamic leptin and insulin signaling. ${ }^{170,171}$ However, a recent paper has shown, using a leptin receptor antagonist, that endogenous leptin signaling and actions in high-fat diet-fed obese mice treated are comparable to those of chow diet-fed mice, arguing against the concept of leptin resistance. ${ }^{172}$ Thus, further studies are needed to clarify the issue of leptin resistance in obese humans and animals.
Diabetes mellitus is a metabolic disorder characterized by hyperglycemia that affects $\sim 9 \%$ of adults worldwide. ${ }^{173}$ It results from deficits in pancreatic insulin secretion and insulin signaling/actions in insulin target organs. Experimental evidence suggests that defective metabolic sensing in hypothalamic neurons may lead to dysregulation of glucose homeostasis and diabetes (Figure 3). Hypothalamic insulin-PI3K signaling is markedly impaired in rats with streptozotocin-induced diabetes. ${ }^{98}$ Pharmacological inhibition of hypothalamic PI3K signaling attenuates the glucose-lowering effect of insulin. Conversely, enhanced hypothalamic PI3K signaling via adenoviral gene therapy potentiates insulin-induced glucose lowering. ${ }^{98}$ Notably, central insulin actions are blunted by short-term high-fat diet feeding. ${ }^{174}$ Thus, a fat-rich diet may contribute to the development of diabetes by disrupting insulin signaling in the hypothalamus. ${ }^{174}$

\section{CONCLUDING REMARKS}

This review highlights the role of the brain in the homeostatic regulation of energy and glucose metabolism. The brain detects energy intake by sensing gut hormones released in response to food intake and detecting nutrients in circulating blood. The brain also monitors body energy stores by sensing adiposityrelated signals. Information on nutrient availability and stored fat is transferred to specialized neurons in the hypothalamus and brain stem. In the control of the energy balance, outflow pathways from the brain regulate food intake and energy expenditure (thermogenesis or locomotor activity).

The brain also has an important role in the maintenance of glucose homeostasis, which is achieved by the modulation of insulin/glucagon secretion in the endocrine pancreas, HGP, and skeletal muscle glucose uptake. The autonomic nervous system constitutes the outflow pathways from the brain to peripheral metabolic organs. Defective crosstalk between the brain and peripheral metabolic organs observed in the obese condition may lead to type 2 diabetes development and obesity progression. Therefore, better understanding of neural mechanisms involved in the regulation of glucose/energy homeostasis will provide us with the opportunity to develop new therapeutics combating obesity and diabetes.

\section{CONFLICT OF INTEREST}

The authors declare no conflict of interest.

\section{ACKNOWLEDGEMENTS}

This work was supported by grants from the National Research Foundation (NRF-2014R1A6A3A01057664, NRF-2013M3C7A1056024 for M-SK) and the Asan Institute for Life Sciences (2013-326).

1 Morton GJ, Meek TH, Schwartz MW. Neurobiology of food intake in health and disease. Nat Rev Neurosci 2014; 15: 367-378.

2 Sandoval D, Cota D, Seeley RJ. The integrative role of CNS fuel-sensing mechanisms in energy balance and glucose regulation. Annu Rev Physiol 2008; 70: 513-535. 
3 Schwartz MW, Porte D Jr. Diabetes, obesity, and the brain. Science 2005; 307: 375-379.

4 Broadwell RD, Brightman MW. Entry of peroxidase into neurons of the central and peripheral nervous systems from extracerebral and cerebral blood. J Comp Neurol 1976; 166: 257-283.

5 Schwartz MW, Woods SC, Porte D Jr, Seeley RJ, Baskin DG. Central nervous system control of food intake. Nature 2000; 404 661-671.

6 Heisler LK, Cowley MA, Tecott LH, Fan W, Low MJ, Smart JL et al. Activation of central melanocortin pathways by fenfluramine. Science 2002; 297: 609-611.

7 Bouret SG, Draper SJ, Simerly RB. Formation of projection pathways from the arcuate nucleus of the hypothalamus to hypothalamic regions implicated in the neural control of feeding behavior in mice. J Neurosci 2004; 24: 2797-2805.

8 Huszar D, Lynch CA, Fairchild-Huntress V, Dunmore JH, Fang Q, Berkemeier LR et al. Targeted disruption of the melanocortin-4 receptor results in obesity in mice. Cell 1997; 88: 131-141.

9 Tao YX. Molecular mechanisms of the neural melanocortin receptor dysfunction in severe early onset obesity. Mol Cell Endocrinol 2005; 239. $1-14$.

10 Ollmann MM, Wilson BD, Yang YK, Kerns JA, Chen Y, Gantz I et al. Antagonism of central melanocortin receptors in vitro and in vivo by agouti-related protein. Science 1997; 278: 135-138.

11 Bewick GA, Gardiner JV, Dhillo WS, Kent AS, White NE, Webster Z et al. Post-embryonic ablation of AgRP neurons in mice leads to a lean, hypophagic phenotype. FASEB J 2005; 19: 1680-1682.

12 Yulyaningsih E, Zhang L, Herzog H, Sainsbury A. NPY receptors as potential targets for anti-obesity drug development. Br J Pharmacol 2011; 163: 1170-1202.

13 Bingham NC, Anderson KK, Reuter AL, Stallings NR, Parker KL. Selective loss of leptin receptors in the ventromedial hypothalamic nucleus results in increased adiposity and a metabolic syndrome. Endocrinology 2008; 149: 2138-2148.

14 Foster MT, Song CK, Bartness TJ. Hypothalamic paraventricular nucleus lesion involvement in the sympathetic control of lipid mobilization. Obesity (Silver Spring) 2010; 18: 682-689.

15 Leibowitz SF, Hammer NJ, Chang K. Hypothalamic paraventricular nucleus lesions produce overeating and obesity in the rat. Physiol Behav 1981; 27: 1031-1040.

16 Gonzalez JA, Reimann F, Burdakov D. Dissociation between sensing and metabolism of glucose in sugar sensing neurones. J Physiol 2009; 587: 41-48.

17 Fei H, Okano HJ, Li C, Lee GH, Zhao C, Darnell R et al. Anatomic localization of alternatively spliced leptin receptors (Ob-R) in mouse brain and other tissues. Proc Natl Acad Sci USA 1997; 94: 7001-7005.

$18 \mathrm{Xu} \mathrm{B}$, Goulding EH, Zang K, Cepoi D, Cone RD, Jones KR et al. Brain-derived neurotrophic factor regulates energy balance downstream of melanocortin-4 receptor. Nat Neurosci 2003; 6: 736-742.

19 Shimizu N, Oomura Y, Plata-Salaman CR, Morimoto M. Hyperphagia and obesity in rats with bilateral ibotenic acid-induced lesions of the ventromedial hypothalamic nucleus. Brain Res 1987; 416: 153-156.

20 Jacobowitz DM, O'Donohue TL. alpha-Melanocyte stimulating hormone: immunohistochemical identification and mapping in neurons of rat brain. Proc Natl Acad Sci USA 1978; 75: 6300-6304.

21 Bernardis LL, Bellinger LL. The dorsomedial hypothalamic nucleus revisited: 1986 update. Brain Res 1987; 434: 321-381.

22 Broberger C, De Lecea L, Sutcliffe JG, Hokfelt T. Hypocretin/orexin- and melanin-concentrating hormone-expressing cells form distinct populations in the rodent lateral hypothalamus: relationship to the neuropeptide $Y$ and agouti gene-related protein systems. J Comp Neurol 1998; 402: 460-474.

23 Ohno K, Sakurai T. Orexin neuronal circuitry: role in the regulation of sleep and wakefulness. Front Neuroendocrinol 2008; 29: 70-87.

24 Hungs M, Mignot E. Hypocretin/orexin, sleep and narcolepsy. Bioessays 2001; 23: 397-408.

25 Marsh DJ, Weingarth DT, Novi DE, Chen HY, Trumbauer ME, Chen AS et al. Melanin-concentrating hormone 1 receptor-deficient mice are lean, hyperactive, and hyperphagic and have altered metabolism. Proc Natl Acad Sci USA 2002; 99: 3240-3245.

26 Schwartz GJ. The role of gastrointestinal vagal afferents in the control of food intake: current prospects. Nutrition 2000; 16: 866-873.

27 Stanley S, Wynne K, McGowan B, Bloom S. Hormonal regulation of food intake. Physiol Rev 2005; 85: 1131-1158.
28 Geerling JC, Shin JW, Chimenti PC, Loewy AD. Paraventricular hypothalamic nucleus: axonal projections to the brain stem. J Comp Neurol 2010; 518: 1460-1499.

29 Ahima RS, Antwi DA. Brain regulation of appetite and satiety. Endocrinol Metab Clin North Am 2008; 37: 811-823.

30 Ellacott KL, Halatchev IG, Cone RD. Characterization of leptin-responsive neurons in the caudal brain stem. Endocrinology 2006; 147: 3190-3195.

31 Hommel JD, Trinko R, Sears RM, Georgescu D, Liu ZW, Gao XB et al. Leptin receptor signaling in midbrain dopamine neurons regulates feeding. Neuron 2006; 51: 801-810.

32 Kim KS, Yoon YR, Lee HJ, Yoon S, Kim SY, Shin SW et al. Enhanced hypothalamic leptin signaling in mice lacking dopamine D2 receptors. J Biol Chem 2010; 285: 8905-8917.

33 Spiegelman BM, Flier JS. Obesity and the regulation of energy balance. Cell 2001; 104: 531-543.

34 Kramer A, Yang FC, Snodgrass P, Li X, Scammell TE, Davis FC et al. Regulation of daily locomotor activity and sleep by hypothalamic EGF receptor signaling. Science 2001; 294: 2511-2515.

35 Samson WK, Bagley SL, Ferguson AV, White MM. Orexin receptor subtype activation and locomotor behaviour in the rat. Acta Physiol (Oxf) 2010; 198: 313-324.

36 Nakamachi T, Matsuda K, Maruyama K, Miura T, Uchiyama M, Funahashi $\mathrm{H}$ et al. Regulation by orexin of feeding behaviour and locomotor activity in the goldfish. J Neuroendocrinol 2006; 18: 290-297.

37 Huo L, Gamber K, Greeley S, Silva J, Huntoon N, Leng XH et al. Leptin-dependent control of glucose balance and locomotor activity by POMC neurons. Cell Metab 2009; 9: 537-547.

38 Minokoshi Y, Kim YB, Peroni OD, Fryer LG, Muller C, Carling D et al. Leptin stimulates fatty-acid oxidation by activating AMP-activated protein kinase. Nature 2002; 415: 339-343.

39 Seale P, Conroe HM, Estall J, Kajimura S, Frontini A, Ishibashi J et al. Prdm16 determines the thermogenic program of subcutaneous white adipose tissue in mice. J Clin Invest 2011; 121: 96-105.

40 Dodd GT, Decherf S, Loh K, Simonds SE, Wiede F, Balland E et al. Leptin and insulin act on POMC neurons to promote the browning of white fat. Cell 2015; 160: 88-104.

41 Morrison SF, Madden CJ, Tupone D. Central neural regulation of brown adipose tissue thermogenesis and energy expenditure. Cell Metab 2014; 19: 741-756.

42 Sacks H, Symonds ME. Anatomical locations of human brown adipose tissue: functional relevance and implications in obesity and type 2 diabetes. Diabetes 2013; 62: 1783-1790.

43 Ouellet V, Routhier-Labadie A, Bellemare W, Lakhal-Chaieb L, Turcotte E, Carpentier AC et al. Outdoor temperature, age, sex, body mass index, and diabetic status determine the prevalence, mass, and glucose-uptake activity of 18F-FDG-detected BAT in humans. J Clin Endocrinol Metab 2011; 96: 192-199.

44 Seoane-Collazo P, Ferno J, Gonzalez F, Dieguez C, Leis R, Nogueiras R et al. Hypothalamic-autonomic control of energy homeostasis. Endocrine 2015; 50: 276-291.

45 Imai-Matsumura K, Matsumura K, Nakayama T. Involvement of ventromedial hypothalamus in brown adipose tissue thermogenesis induced by preoptic cooling in rats. Jpn J Physiol 1984; 34: 939-943.

46 Yoshida K, Li X, Cano G, Lazarus M, Saper CB. Parallel preoptic pathways for thermoregulation. J Neurosci 2009; 29: 11954-11964.

47 Zhang $\mathrm{Y}$, Kerman IA, Laque A, Nguyen P, Faouzi M, Louis GW et al. Leptin-receptor-expressing neurons in the dorsomedial hypothalamus and median preoptic area regulate sympathetic brown adipose tissue circuits. J Neurosci 2011; 31: 1873-1884.

48 Chao PT, Yang L, Aja S, Moran TH, Bi S. Knockdown of NPY expression in the dorsomedial hypothalamus promotes development of brown adipocytes and prevents diet-induced obesity. Cell Metab 2011; 13: 573-583.

49 Brito MN, Brito NA, Baro DJ, Song CK, Bartness TJ. Differential activation of the sympathetic innervation of adipose tissues by melanocortin receptor stimulation. Endocrinology 2007; 148: 5339-5347.

50 Haynes WG, Morgan DA, Djalali A, Sivitz WI, Mark AL. Interactions between the melanocortin system and leptin in control of sympathetic nerve traffic. Hypertension 1999; 33: 542-547.

51 Lockie SH, Heppner KM, Chaudhary N, Chabenne JR, Morgan DA, Veyrat-Durebex $\mathrm{C}$ et al. Direct control of brown adipose tissue thermogenesis by central nervous system glucagon-like peptide-1 receptor signaling. Diabetes 2012; 61: 2753-2762. 
52 Rahmouni K, Morgan DA, Morgan GM, Liu X, Sigmund CD, Mark AL et al. Hypothalamic PI3K and MAPK differentially mediate regional sympathetic activation to insulin. J Clin Invest 2004; 114: 652-658.

53 Rothwell NJ, Stock MJ. A role for insulin in the diet-induced thermogenesis of cafeteria-fed rats. Metabolism 1981; 30: 673-678.

54 Schwartz RS, Jaeger LF, Veith RC. Effect of clonidine on the thermic effect of feeding in humans. Am J Physiol 1988; 254: R90-R94.

55 Cannon B, Nedergaard J. Brown adipose tissue: function and physiological significance. Physiol Rev 2004; 84: 277-359.

56 Seeley RJ, Woods SC. Monitoring of stored and available fuel by the CNS: implications for obesity. Nat Rev Neurosci 2003; 4: 901-909.

57 Woods SC, Lotter EC, McKay LD, Porte D Jr. Chronic intracerebroventricular infusion of insulin reduces food intake and body weight of baboons. Nature 1979; 282: 503-505.

58 Bagdade JD, Bierman EL, Porte D Jr. The significance of basal insulin levels in the evaluation of the insulin response to glucose in diabetic and nondiabetic subjects. J Clin Invest 1967; 46: 1549-1557.

59 Air EL, Benoit SC, Blake Smith KA, Clegg DJ, Woods SC. Acute third ventricular administration of insulin decreases food intake in two paradigms. Pharmacol Biochem Behav 2002; 72: 423-429.

60 Chavez M, Kaiyala K, Madden LJ, Schwartz MW, Woods SC. Intraventricular insulin and the level of maintained body weight in rats. Behav Neurosci 1995; 109: 528-531.

61 Bruning JC, Gautam D, Burks DJ, Gillette J, Schubert M, Orban PC et al. Role of brain insulin receptor in control of body weight and reproduction. Science 2000; 289: 2122-2125.

62 White MF. Insulin signaling in health and disease. Science 2003; 302: 1710-1711.

63 Maffei M, Stoffel M, Barone M, Moon B, Dammerman M, Ravussin E et al. Absence of mutations in the human $\mathrm{OB}$ gene in obese/diabetic subjects. Diabetes 1996; 45: 679-682.

64 Considine RV, Sinha MK, Heiman ML, Kriauciunas A, Stephens TW, Nyce MR et al. Serum immunoreactive-leptin concentrations in normal-weight and obese humans. N Eng/ J Med 1996; 334: 292-295.

65 Tartaglia LA, Dembski M, Weng X, Deng N, Culpepper J, Devos R et al. Identification and expression cloning of a leptin receptor, OB-R. Cell 1995; 83: 1263-1271.

66 Coppari R, Ichinose M, Lee CE, Pullen AE, Kenny CD, McGovern RA et al. The hypothalamic arcuate nucleus: a key site for mediating leptin's effects on glucose homeostasis and locomotor activity. Cell Metab 2005; 1: 63-72.

67 Satoh N, Ogawa Y, Katsuura G, Hayase M, Tsuji T, Imagawa K et al. The arcuate nucleus as a primary site of satiety effect of leptin in rats. Neurosci Lett 1997; 224: 149-152.

68 Oswal A, Yeo G. Leptin and the control of body weight: a review of its diverse central targets, signaling mechanisms, and role in the pathogenesis of obesity. Obesity (Silver Spring) 2010; 18: 221-229.

69 Myers MG Jr, Olson DP. Central nervous system control of metabolism. Nature 2012; 491: 357-363.

70 Obici S, Feng Z, Morgan K, Stein D, Karkanias G, Rossetti L. Central administration of oleic acid inhibits glucose production and food intake. Diabetes 2002; 51: 271-275.

71 Miselis RR, Epstein AN. Feeding induced by intracerebroventricular 2-deoxy-D-glucose in the rat. Am J Physiol 1975; 229: 1438-1447.

72 Foster DW. Malonyl-CoA: the regulator of fatty acid synthesis and oxidation. J Clin Invest 2012; 122: 1958-1959.

73 Clegg DJ, Wortman MD, Benoit SC, McOsker CC, Seeley RJ. Comparison of central and peripheral administration of C75 on food intake, body weight, and conditioned taste aversion. Diabetes 2002; 51: 3196-3201.

74 Obici S, Feng Z, Arduini A, Conti R, Rossetti L. Inhibition of hypothalamic carnitine palmitoyltransferase- 1 decreases food intake and glucose production. Nat Med 2003; 9: 756-761.

75 Kennedy GC. The role of depot fat in the hypothalamic control of food intake in the rat. Proc $R$ Soc Lond B Biol Sci 1953; 140: 578-596.

76 Baggio LL, Drucker DJ. Glucagon-like peptide-1 receptors in the brain: controlling food intake and body weight. J Clin Invest 2014; 124: 4223-4226.

77 Merchenthaler I, Lane M, Shughrue P. Distribution of pre-pro-glucagon and glucagon-like peptide-1 receptor messenger RNAs in the rat central nervous system. J Comp Neurol 1999; 403: 261-280.

78 Chelikani PK, Haver AC, Reidelberger RD. Intravenous infusion of glucagon-like peptide-1 potently inhibits food intake, sham feeding, and gastric emptying in rats. Am J Physiol Regul Integr Comp Physiol 2005; 288: R1695-R1706.
79 Tang-Christensen M, Larsen PJ, Goke R, Fink-Jensen A, Jessop DS, Moller $\mathrm{M}$ et al. Central administration of GLP-1-(7-36) amide inhibits food and water intake in rats. Am J Physiol 1996; 271: R848-R856.

80 Cummings DE, Clement K, Purnell JQ, Vaisse C, Foster KE, Frayo RS et al. Elevated plasma ghrelin levels in Prader Willi syndrome. Nat Med 2002; 8: 643-644.

81 Febbraio MA, Pedersen BK. Muscle-derived interleukin-6: mechanisms for activation and possible biological roles. FASEB J 2002; 16: 1335-1347.

82 Wallenius V, Wallenius K, Ahren B, Rudling M, Carlsten H, Dickson SL et al. Interleukin-6-deficient mice develop mature-onset obesity. Nat Med 2002; 8: 75-79.

83 Lutz TA. Control of energy homeostasis by amylin. Cell Mol Life Sci 2012; 69: 1947-1965.

84 Campbell JE, Drucker DJ. Islet $\alpha$ cells and glucagon - critical regulators of energy homeostasis. Nat Rev Endocrinol 2015; 11: 329-338.

85 Asakawa A, Inui A, Yuzuriha H, Ueno N, Katsuura G, Fujimiya M et al. Characterization of the effects of pancreatic polypeptide in the regulation of energy balance. Gastroenterology 2003; 124: 1325-1336.

86 Woods SC, Lutz TA, Geary N, Langhans W. Pancreatic signals controlling food intake; insulin, glucagon and amylin. Philos Trans $R$ Soc Lond B Biol Sci 2006; 361: 1219-1235.

87 Bernard C. Leçons de physiologie expérimentale appliquée à la médecine. Ballière et Fils: Paris, France, 1855.

88 Anand B, Chhina G, Sharma K, Dua S, Singh B. Activity of single neurons in the hypothalamic feeding centers: effect of glucose. Am J Physiol 1964; 207: 1146-1154.

89 Oomura Y, Ono T, Ooyama H, Wayner M. Glucose and osmosensitive neurones of the rat hypothalamus. Nature 1969; 222: 282-284.

90 Borg MA, Sherwin RS, Borg WP, Tamborlane WV, Shulman GI. Local ventromedial hypothalamus glucose perfusion blocks counterregulation during systemic hypoglycemia in awake rats. J Clin Invest 1997; 99: 361-365

91 Routh VH. Glucose-sensing neurons: are they physiologically relevant? Physiol Behav 2002; 76: 403-413.

92 Dunn-Meynell AA, Rawson NE, Levin BE. Distribution and phenotype of neurons containing the ATP-sensitive $\mathrm{K}+$ channel in rat brain. Brain Res 1998; 814: 41-54.

93 Mizuno Y, Oomura Y. Glucose responding neurons in the nucleus tractus solitarius of the rat: in vitro study. Brain Res 1984; 307: 109-116.

94 Funahashi M. Adachi A. Glucose-responsive neurons exist within the area postrema of the rat: in vitro study on the isolated slice preparation. Brain Res Bull 1993; 32: 531-535.

95 Yettefti K, Orsini J-C, Perrin J. Characteristics of glycemia-sensitive neurons in the nucleus tractus solitarii: possible involvement in nutritional regulation. Physiol Behav 1997; 61: 93-100.

96 Obici S, Feng Z, Karkanias G, Baskin DG, Rossetti L. Decreasing hypothalamic insulin receptors causes hyperphagia and insulin resistance in rats. Nat Neurosci 2002; 5: 566-572.

97 Obici S, Zhang BB, Karkanias G, Rossetti L. Hypothalamic insulin signaling is required for inhibition of glucose production. Nat Med 2002; 8: 1376-1382.

98 Gelling RW, Morton GJ, Morrison CD, Niswender KD, Myers MG, Rhodes CJ et al. Insulin action in the brain contributes to glucose lowering during insulin treatment of diabetes. Cell Metab 2006; 3: 67-73.

99 Spanswick D, Smith M, Mirshamsi S, Routh V. Ashford M. Insulin activates ATP-sensitive $\mathrm{K}^{\wedge}+$ channels in hypothalamic neurons of lean, but not obese rats. Nat Neurosci 2000; 3: 757-758.

100 Pocai A, Lam TK, Gutierrez-Juarez R, Obici S, Schwartz GJ, Bryan J et al. Hypothalamic KATP channels control hepatic glucose production. Nature 2005; 434: 1026-1031.

101 Inoue H, Ogawa W, Asakawa A, Okamoto Y, Nishizawa A, Matsumoto M et al. Role of hepatic STAT3 in brain-insulin action on hepatic glucose production. Cell Metab 2006; 3: 267-275.

102 Coleman D. Obese and diabetes: two mutant genes causing diabetesobesity syndromes in mice. Diabetologia 1978; 14: 141-148.

103 Halaas JL, Gajiwala KS, Maffei M, Cohen SL, Chait BT, Rabinowitz D et al. Weight-reducing effects of the plasma protein encoded by the obese gene. Science 1995; 269: 543-546.

104 Pelleymounter MA, Cullen MJ, Baker MB, Hecht R, Winters D, Boone T et al. Effects of the obese gene product on body weight regulation in ob/ob mice. Science 1995; 269: 540-543.

105 Rossetti L, Massillon D, Barzilai N, Vuguin P, Chen W, Hawkins M et al. Short term effects of leptin on hepatic gluconeogenesis and in vivo insulin action. J Biol Chem 1997; 272: 27758-27763. 
106 Liu L, Karkanias GB, Jose'C M, Hawkins M, Barzilai N, Wang J et al. Intracerebroventricular leptin regulates hepatic but not peripheral glucose fluxes. J Biol Chem 1998; 273: 31160-31167.

107 Schwartz MW, Baskin DG, Bukowski TR, Kuijper JL, Foster D, Lasser G et al. Specificity of leptin action on elevated blood glucose levels and hypothalamic neuropeptide $Y$ gene expression in ob/ob mice. Diabetes 1996; 45: 531-535.

108 Shimomura I, Hammer RE, Ikemoto S, Brown MS, Goldstein JL. Leptin reverses insulin resistance and diabetes mellitus in mice with congenital lipodystrophy. Nature 1999; 401: 73-76.

109 Ebihara K, Ogawa Y, Masuzaki H, Shintani M, Miyanaga F, Aizawa-Abe M et al. Transgenic overexpression of leptin rescues insulin resistance and diabetes in a mouse model of lipoatrophic diabetes. Diabetes 2001; 50: $1440-1448$

110 Asilmaz E, Cohen P, Miyazaki M, Dobrzyn P, Ueki K, Fayzikhodjaeva G et al. Site and mechanism of leptin action in a rodent form of congenital lipodystrophy. J Clin Invest 2004; 113: 414-424.

111 Pocai A, Morgan K, Buettner C, Gutierrez-Juarez R, Obici S, Rossetti L. Central leptin acutely reverses diet-induced hepatic insulin resistance. Diabetes 2005; 54: 3182-3189.

112 Coppari R, Ichinose M, Lee CE, Pullen AE, Kenny CD, McGovern RA et al. The hypothalamic arcuate nucleus: a key site for mediating leptin's effects on glucose homeostasis and locomotor activity. Cell Metab 2005; 1 : 63-72.

113 Buettner C, Pocai A, Muse ED, Etgen AM, Myers MG, Rossetti L. Critical role of STAT3 in leptin's metabolic actions. Cell Metab 2006; 4: 49-60.

114 Kievit P, Howard JK, Badman MK, Balthasar N, Coppari R, Mori H et al. Enhanced leptin sensitivity and improved glucose homeostasis in mice lacking suppressor of cytokine signaling-3 in POMC-expressing cells. Cell Metab 2006; 4: 123-132.

115 Morton GJ, Gelling RW, Niswender KD, Morrison CD, Rhodes CJ, Schwartz MW. Leptin regulates insulin sensitivity via phosphatidylinositol-3-OH kinase signaling in mediobasal hypothalamic neurons. Cell Metab 2005; 2: 411-420.

116 Borg WP, Sherwin RS, During MJ, Borg MA, Shulman Gl. Local ventromedial hypothalamus glucopenia triggers counterregulatory hormone release. Diabetes 1995; 44: 180-184.

117 Ritter S, Dinh TT, Zhang Y. Localization of hindbrain glucoreceptive sites controlling food intake and blood glucose. Brain Res 2000; 856 37-47.

118 Ritter S, Bugarith K, Dinh TT. Immunotoxic destruction of distinct catecholamine subgroups produces selective impairment of glucoregulatory responses and neuronal activation. J Comp Neurol 2001; 432: 197-216.

119 Schuit FC, Huypens P, Heimberg H, Pipeleers DG. Glucose sensing in pancreatic $\beta$-cells a model for the study of other glucose-regulated cells in gut, pancreas, and hypothalamus. Diabetes 2001; 50: 1-11.

120 Marty N, Dallaporta M, Thorens B. Brain glucose sensing, counterregulation, and energy homeostasis. Physiology 2007; 22: 241-251.

121 Burcelin R, Thorens B. Evidence that extrapancreatic GLUT2-dependent glucose sensors control glucagon secretion. Diabetes 2001; 50: 1282-1289.

122 Marty N, Dallaporta M, Foretz M, Emery M, Tarussio D, Bady I et al. Regulation of glucagon secretion by glucose transporter type 2 (glut2) and astrocyte-dependent glucose sensors. J Clin Invest 2005; 115: 3545-3553.

123 Sanders NM, Dunn-Meynell AA, Levin BE. Third ventricular alloxan reversibly impairs glucose counterregulatory responses. Diabetes 2004; 53: $1230-1236$

124 Miki T, Liss B, Minami K, Shiuchi T, Saraya A, Kashima Y et al. ATP-sensitive $K+$ channels in the hypothalamus are essential for the maintenance of glucose homeostasis. Nat Neurosci 2001; 4: 507-512.

125 Evans ML, McCrimmon RJ, Flanagan DE, Keshavarz T, Fan X, McNay EC et al. Hypothalamic ATP-sensitive $\mathrm{K}+$ channels play a key role in sensing hypoglycemia and triggering counterregulatory epinephrine and glucagon responses. Diabetes 2004; 53: 2542-2551.

126 McCrimmon RJ, Evans ML, Fan X, McNay EC, Chan O, Ding Y et al. Activation of ATP-sensitive $\mathrm{K}+$ channels in the ventromedial hypothalamus amplifies counterregulatory hormone responses to hypoglycemia in normal and recurrently hypoglycemic rats. Diabetes 2005; 54: 3169-3174.

127 Oomura Y, Ooyama H, Sugimori M, Nakamura T, Yamada Y. Glucose inhibition of the glucose-sensitive neurone in the rat lateral hypothalamus. Nature 1974; 247: 284-286.
128 Song Z, Levin BE, McArdle JJ, Bakhos N, Routh VH. Convergence of preand postsynaptic influences on glucosensing neurons in the ventromedial hypothalamic nucleus. Diabetes 2001; 50: 2673-2681.

129 Hardie DG, Carling D, Carlson M. The AMP-activated/SNF1 protein kinase subfamily: metabolic sensors of the eukaryotic cell? Annu Rev Biochem 1998; 67: 821-855.

130 Rutter G, daSilva Xavier G, Leclerc I. Roles of 5'-AMP-activated protein kinase (AMPK) in mammalian glucose homoeostasis. Biochem J 2003; 375: 1-16.

131 Kim M-S, Park J-Y, Namkoong C, Jang P-G, Ryu J-W, Song H-S et al. Anti-obesity effects of $\alpha$-lipoic acid mediated by suppression of hypothalamic AMP-activated protein kinase. Nat Med 2004; 10: 727-733.

132 Minokoshi Y, Alquier T, Furukawa N, Kim Y-B, Lee A, Xue B et al. AMP-kinase regulates food intake by responding to hormonal and nutrient signals in the hypothalamus. Nature 2004; 428: 569-574.

133 McCrimmon RJ, Fan X, Ding Y, Zhu W, Jacob RJ, Sherwin RS. Potential role for AMP-activated protein kinase in hypoglycemia sensing in the ventromedial hypothalamus. Diabetes 2004; 53: 1953-1958.

134 McCrimmon RJ, Fan X, Cheng H, McNay E, Chan O, Shaw M et al. Activation of AMP-activated protein kinase within the ventromedial hypothalamus amplifies counterregulatory hormone responses in rats with defective counterregulation. Diabetes 2006; 55: 1755-1760.

135 Han S-M, Namkoong C, Jang P, Park I, Hong S, Katakami H et al. Hypothalamic AMP-activated protein kinase mediates counter-regulatory responses to hypoglycaemia in rats. Diabetologia 2005; 48: 2170-2178.

136 Lam TK, Pocai A, Gutierrez-Juarez R, Obici S, Bryan J, Aguilar-Bryan L et al. Hypothalamic sensing of circulating fatty acids is required for glucose homeostasis. Nat Med 2005; 11: 320-327.

137 Okamoto H, Obici S, Accili D, Rossetti L. Restoration of liver insulin signaling in Insr knockout mice fails to normalize hepatic insulin action. J Clin Invest 2005; 115: 1314-1322.

138 Lin HV, Plum L, Ono H, Gutiérrez-Juárez R, Shanabrough M, Borok E et al. Divergent regulation of energy expenditure and hepatic glucose production by insulin receptor in agouti-related protein and POMC neurons. Diabetes 2010; 59: 337-346.

139 Ramnanan CJ, Saraswathi V, Smith MS, Donahue EP, Farmer B, Farmer TD et al. Brain insulin action augments hepatic glycogen synthesis without suppressing glucose production or gluconeogenesis in dogs. J Clin Invest 2011; 121: 3713-3723.

140 Cherrington A, Moore M, Sindelar D, Edgerton D. Insulin action on the liver in vivo. Biochem Soc Trans 2007; 35: 1171-1174.

141 Hendrick GK, Frizzell RT, Williams PE, Cherrington AD. Effect of hyperglucagonemia on hepatic glycogenolysis and gluconeogenesis after a prolonged fast. Am J Physiol 1990; 258: E841-E849.

142 Nuttall FQ, Ngo A, Gannon MC. Regulation of hepatic glucose production and the role of gluconeogenesis in humans: is the rate of gluconeogenesis constant? Diabetes Metab Res Rev 2008; 24: 438-458.

143 Kokubun E, Hirabara SM, Fiamoncini J, Curi R, Haebisch H. Changes of glycogen content in liver, skeletal muscle, and heart from fasted rats. Cell Biochem Funct 2009; 27: 488-495.

144 Shimazu T, Sudo M, Minokoshi Y, Takahashi A. Role of the hypothalamus in insulin-independent glucose uptake in peripheral tissues. Brain Res Bull 1991; 27: 501-504.

145 Sudo M, Minokoshi Y, Shimazu T. Ventromedial hypothalamic stimulation enhances peripheral glucose uptake in anesthetized rats. Am J Physiol 1991; 261: E298-E303.

146 Minokoshi Y, Okano Y, Shimazu T. Regulatory mechanism of the ventromedial hypothalamus in enhancing glucose uptake in skeletal muscles. Brain Res 1994; 649: 343-347.

147 Minokoshi Y, Haque MS, Shimazu T. Microinjection of leptin into the ventromedial hypothalamus increases glucose uptake in peripheral tissues in rats. Diabetes 1999; 48: 287-291.

148 Roman EA, Reis D, Romanatto T, Maimoni D, Ferreira EA, Santos GA et al. Central leptin action improves skeletal muscle AKT, AMPK, and PGC1 $\alpha$ activation by hypothalamic PI3K-dependent mechanism. Mol Cell Endocrinol 2010; 314: 62-69.

149 Koch C, Augustine RA, Steger J, Ganjam GK, Benzler J, Pracht C et al. Leptin rapidly improves glucose homeostasis in obese mice by increasing hypothalamic insulin sensitivity. J Neurosci 2010; 30: 16180-16187.

150 Funai K, Cartee GD. Inhibition of contraction-stimulated AMP-activated protein kinase inhibits contraction-stimulated increases in PAS-TBC1D1 and glucose transport without altering PAS-AS160 in rat skeletal muscle. Diabetes 2009; 58: 1096-1104. 
151 Hutchinson DS, Bengtsson T. AMP-activated protein kinase activation by adrenoceptors in L6 skeletal muscle cells mediation by $\alpha 1$-adrenoceptors causing glucose uptake. Diabetes 2006; 55: 682-690.

152 Minokoshi Y, Kim Y-B, Peroni OD, Fryer LG, Müller C, Carling D et al. Leptin stimulates fatty-acid oxidation by activating AMP-activated protein kinase. Nature 2002; 415: 339-343.

153 Shiuchi T, Haque MS, Okamoto S, Inoue T, Kageyama H, Lee S et al. Hypothalamic orexin stimulates feeding-associated glucose utilization in skeletal muscle via sympathetic nervous system. Cell Metab 2009; 10: 466-480.

154 Ahrén B. Autonomic regulation of islet hormone secretion-implications for health and disease. Diabetologia 2000; 43: 393-410.

155 Satin LS, Kinard TA. Neurotransmitters and their receptors in the islets of Langerhans of the pancreas. Endocrine 1998; 8: 213-223.

156 Thorens B. Central control of glucose homeostasis: the brain-endocrine pancreas axis. Diabetes Metab 2010; 36: S45-S49.

157 Ionescu E, Rohner-Jeanrenaud F, Berthoud H-R, Jeanrenaud B. Increases in plasma insulin levels in response to electrical stimulation of the dorsal motor nucleus of the vagus nerve. Endocrinology 1983; 112 904-910.

158 Chen M, Woods SC, Porte D. Effect of cerebral intraventricular insulin on pancreatic insulin secretion in the dog. Diabetes 1975; 24: 910-914.

159 Paranjape SA, Chan O, Zhu W, Horblitt AM, McNay EC, Cresswell JA et al. Influence of insulin in the ventromedial hypothalamus on pancreatic glucagon secretion in vivo. Diabetes 2010; 59: $1521-1527$

160 Thorens B. Brain glucose sensing and neural regulation of insulin and glucagon secretion. Diabetes Obes Metab 2011; 13: 82-88.

161 Caro JF, Kolaczynski JW, Nyce MR, Ohannesian JP, Opentanova I, Goldman WH et al. Decreased cerebrospinal-fluid/serum leptin ratio in obesity: a possible mechanism for leptin resistance. Lancet 1996; 348: 159-161.

162 Maes HH, Neale MC, Eaves LJ. Genetic and environmental factors in relative body weight and human adiposity. Behav Genet 1997; 27: 325-351.

163 Kubota N, Terauchi Y, Tobe K, Yano W, Suzuki R, Ueki K et al. Insulin receptor substrate 2 plays a crucial role in beta cells and the hypothalamus. J Clin Invest 2004; 114: 917-927.

164 Gao Q, Wolfgang MJ, Neschen S, Morino K, Horvath TL, Shulman Gl et al. Disruption of neural signal transducer and activator of transcription 3 causes obesity, diabetes, infertility, and thermal dysregulation. Proc Natl Acad Sci USA 2004; 101: 4661-4666.
165 El-Haschimi K, Pierroz DD, Hileman SM, Bjørbæk C, Flier JS. Two defects contribute to hypothalamic leptin resistance in mice with diet-induced obesity. J Clin Invest 2000; 105: 1827-1832.

166 Mori H, Hanada R, Hanada T, Aki D, Mashima R, Nishinakamura H et al. Socs3 deficiency in the brain elevates leptin sensitivity and confers resistance to diet-induced obesity. Nat Med 2004; 10: 739-743.

167 Egawa K, Maegawa H, Shimizu S, Morino K, Nishio Y, Bryer-Ash M et al. Protein-tyrosine phosphatase-1B negatively regulates insulin signaling in 16 myocytes and Fao hepatoma cells. J Biol Chem 2001; 276: 10207-10211.

168 Kaszubska W, Falls HD, Schaefer VG, Haasch D, Frost L, Hessler P et al. Protein tyrosine phosphatase $1 \mathrm{~B}$ negatively regulates leptin signaling in a hypothalamic cell line. Mol Cell Endocrinol 2002; 195: 109-118.

169 Bence KK, Delibegovic M, Xue B, Gorgun CZ, Hotamisligil GS, Neel BG et al. Neuronal PTP1B regulates body weight, adiposity and leptin action. Nat Med 2006; 12: 917-924.

170 Zhang X, Zhang G, Zhang H, Karin M, Bai H, Cai D. Hypothalamic IKK $\beta /$ NF-KB and ER stress link overnutrition to energy imbalance and obesity. Cell 2008; 135: 61-73.

171 Ozcan L, Ergin AS, Lu A, Chung J, Sarkar S, Nie D et al. Endoplasmic reticulum stress plays a central role in development of leptin resistance. Cell Metab 2009; 9: 35-51.

172 Ottaway N, Mahbod P, Rivero B, Norman LA, Gertler A, D'Alessio DA et al. Diet-induced obese mice retain endogenous leptin action. Cell Metab 2015; 21: 877-882.

173 Alwan A. Global Status Report on Noncommunicable Diseases 2010. World Health Organization: Geneva, Switzerland, 2011.

174 Ono H, Pocai A, Wang Y, Sakoda H, Asano T, Backer JM et al. Activation of hypothalamic S6 kinase mediates diet-induced hepatic insulin resistance in rats. J Clin Invest 2008; 118: 2959-2968.

(c) (1) (2)(2) This work is licensed under a Creative Commons Attribution-NonCommercial-ShareAlike 4.0 International License. The images or other third party material in this article are included in the article's Creative Commons license, unless indicated otherwise in the credit line; if the material is not included under the Creative Commons license, users will need to obtain permission from the license holder to reproduce the material. To view a copy of this license, visit http:// creativecommons.org/licenses/by-nc-sa/4.0/ 